\title{
Thermodynamics Process Simulation Based Design of High Performance Light Integrated Coal Gasification Fuel Cell Plant with Membrane-Based $\mathrm{CO}_{2}$ Capture Technology
}

\author{
Adi Saputra ${ }^{1, *}$ and Michihisa Koyama ${ }^{2}$
}

\begin{abstract}
The Light Integrated Coal Gasification Fuel Cell (L-IGFC) plant technology is one of the most promising technologies in the coal utilization for power generation. It could reach maximum efficiency $60.32 \%$ in LHV when the operating pressure and temperature of SOFC are $3 \mathrm{~atm}$ and $850{ }^{\circ} \mathrm{C}$, respectively. However, this plant has not equipped yet with $\mathrm{CO}_{2}$ capture technology to mitigate $\mathrm{CO}_{2}$ emission. In another issue, the integration of $\mathrm{CO}_{2}$ capture technology in a plant system significantly could reduce the total system efficiency. Therefore, in this study, a membrane-based $\mathrm{CO}_{2}$ capture technology which is equipped with heat recovery systems is established to remove $\mathrm{CO}_{2}$ before entering into the SOFC module. The total efficiency of the proposed system is $62.50 \%$ which is 2.18 points higher than the reference system without $\mathrm{CO}_{2}$ capture. Thus, the L-IGFC plant integrated with membrane-based $\mathrm{CO}_{2}$ capture technology could avoid the efficiency penalty.
\end{abstract}

Keywords-Efficiency penalty, heat recovery system, L-IGFC plant, membrane-based $\mathrm{CO}_{2}$ capture.

\section{INTRODUCTION}

The increase of population and economic growth has contributed to the increase in energy consumption in the world especially for fossil fuels consumption in the power generation plant. Many ways have been done in order to find an alternative solution in improving the efficiency of a power generation plant. One of them is light integrated coal gasification fuel cell (L-IGFC) plant. The L-IGFC plant is a system integration of solid oxide fuel cell (SOFC) in coal gasification power plant which recognized as one of high efficiency plants for electricity generation in a sustainable future [1]. It is one of the most promising technologies in the coal utilization for power generation. The L-IGFC plant has been designed and investigated thermodynamically with clean syngas as fuel for SOFC and could reach maximum efficiency $60.32 \%$ in LHV when the operating pressure and temperature of SOFC are $3 \mathrm{~atm}$ and $850^{\circ} \mathrm{C}$, respectively [2]. However, this future power generation plant has not equipped yet with $\mathrm{CO}_{2}$

Adi Saputra ${ }^{1}$ is with the Department of Hydrogen Energy Systems, Kyushu University, Japan.

Michihisa Koyama ${ }^{2}$ is with the Department of Hydrogen Energy Systems, Kyushu University and with the INAMORI Frontier Research Center, Kyushu University, Japan. capture technology to mitigate $\mathrm{CO}_{2}$ compound. The use of fossil fuels for power generation and industrial process is one of the main causes of the anthropogenic $\mathrm{CO}_{2}$ concentration increasing in the atmosphere [3]. The $\mathrm{CO}_{2}$ emissions from fossil fuel combustion and industrial processes, account for $78 \%$ of the increase in greenhouse gas emissions between 1970 and 2010 [4]. Different approaches are also considered and adopted by various countries to reduce their $\mathrm{CO}_{2}$ emission, one of them is carbon capture technologies [5].

Currently, the technology of CCS or also recognized as $\mathrm{CO}_{2}$ capture technology has received a big attention in worldwide to reduce $\mathrm{CO}_{2}$ emission [4][6][7]. However, integration of $\mathrm{CO}_{2}$ capture technology in the power generation system could reduce significantly the total plant efficiency approximately $10 \%$ [8]. Therefore, in this study, a membrane-based $\mathrm{CO}_{2}$ capture technology which is equipped with heat recovery systems is established to removes $\mathrm{CO}_{2}$ compound without reduce the total efficiency of the plant. This study proposed a high efficiency L-IGFC system with membrane-based $\mathrm{CO}_{2}$ capture technology and thermodynamically analyzes performance of the proposed system.

\section{METHODOLOGY}

\section{A. The Light Integrated Coal Gasification Fuel Cell Plant}

Aspen Plus has been used for modeling the whole system in the current study including the L-IGFC plant. The performance of SOFC in the system is analyzed and calculated by using Microsoft Excel software. The detail configurations, operational conditions, input parameters, and performance calculation of reference L-IGFC system could be referred to the previous published studies [1][2].

\section{B. Water Gas Shift Reaction}

The clean syngas before entering into the SOFC unit must be converted to a hydrogen-rich syngas when dealing with $\mathrm{CO}_{2}$ separation in the L-IGFC system. The clean syngas will react with steam to produce more $\mathrm{H}_{2}$ and $\mathrm{CO}_{2}$ in two adiabatic tubular reactors packed with catalyst before entering into the $\mathrm{CO}_{2}$ membrane. The water gas shift reaction which occurs in the reactors is: 


$$
\mathrm{CO}+\mathrm{H}_{2} \mathrm{O} \rightarrow \mathrm{H}_{2}+\mathrm{CO}_{2} \quad \Delta \mathrm{H}_{298}^{0}=41.1 \mathrm{~kJ} / \mathrm{mol}
$$

In this study, the water gas shift reactors of NETL/ DOE are adopted and have been verified with practical data [9][10]. The operating parameter of water gas shift reaction is shown in the following TABLE I.

TABLE I:

OPERATING PARAMETER OF WATER GAS SHIFT REACTION

\begin{tabular}{lc} 
Number of reactor & 2 \\
Inlet temperature of reactor $1,{ }^{\circ} \mathrm{C}$ & 230 \\
Inlet temperature of reactor $2,{ }^{\circ} \mathrm{C}$ & 232 \\
Operating pressure, bar & 40 \\
Pressure drop, bar & 0.69 \\
Steam/ CO ratio & 2 \\
Type of catalyst & $\mathrm{Cu} / \mathrm{ZnO} / \mathrm{Al}_{2} \mathrm{O}_{3}$ \\
bed voidage $(\varepsilon)$ & 0.5 \\
particle density $(\rho), \mathrm{lb} / \mathrm{ft}^{3}$ & 150 \\
CO conversion, $\%$ & 99.32 \\
\hline
\end{tabular}

\section{Membrane-Based $\mathrm{CO}_{2}$ capture}

The Polaris ${ }^{\mathrm{TM}}$ membrane has adopted to remove $\mathrm{CO}_{2}$ emission from L-IGFC power plant [11][12]. In practical separation application, the pressure ratio across the membrane is between 5 and 15 [13] but in this study, pressure ratio 10 was chosen. The feed and permeate pressure of membrane are $10 \mathrm{~atm}$ and $1 \mathrm{~atm}$, respectively with working temperature of membrane $10{ }^{\circ} \mathrm{C}$. The separation properties of the membrane are shown in TABLE II.

\begin{tabular}{cc} 
TABLE II: \\
\multicolumn{2}{c}{ Separation Properties OF Membrane At $10^{\circ} \mathrm{C}[14]$} \\
\hline Gas Component & Mixed Gas Permeance $\left(\mathrm{GPU}^{\mathrm{a}}\right)$ \\
\hline $\mathrm{CO}_{2}$ & 1,000 \\
$\mathrm{H}_{2}$ & 85 \\
$\mathrm{CO}$ & 20 \\
$\mathrm{~N}_{2}$ & 10 \\
$\mathrm{CH}_{4}$ & 10 \\
$\mathrm{H}_{2} \mathrm{~S}$ & 2,000 \\
\hline${ }^{\mathrm{a}} 1 \mathrm{GPU}=7.501 \times 10^{-12} \mathrm{~m}^{3}(\mathrm{STP}) /\left(\mathrm{m}^{2}\right.$.s.Pa)
\end{tabular}

\section{RESUlTS AND Discussion}

This study proposes a new configuration of L-IGFC plant which integrates with membrane-based $\mathrm{CO}_{2}$ capture to remove $\mathrm{CO}_{2}$ compound. The proposed configuration is shown in Fig. 1. The operating parameter of reference L-IGFC system has published in previous study [1][2]. The $\mathrm{CO}_{2}$ membrane in the L-IGFC does not consume energy because it does not require vacuum pump during operation. The membrane is driven by pressure difference which is in this study, pressure difference 10 is chosen. The permeate pressure of the membrane is set to ambient pressure $1 \mathrm{~atm}$ while the feed pressure is $10 \mathrm{~atm}$.

Approximately $88.88 \%$ of $\mathrm{CO}_{2}$ compound will be captured from feed stream and will deliver to intercooling $\mathrm{CO}_{2}$ compression through permeate stream. However, before entering into the membrane unit, the desulphurized syngas is converted to hydrogen-rich syngas with $\mathrm{CO}_{2}$ product through water gas shift reactors. Steam is required to convert $\mathrm{CO}_{2}$ into $\mathrm{H}_{2}$ and $\mathrm{CO}_{2}$ through water gas shift reaction. This steam can be generated with borrowing heat from syngas cooler (steam drum unit) and return that heat after gain additional heat from multi-stream heat exchanger. The mass flow rate of water which is pumped to the steam drum is increase because the additional water mass flow rate will be used to generate steam for water gas shift reaction process and produce electricity through steam turbines (HPST2 and LPST2). The heat recovery system has applied in the water gas reaction process and membrane system. So, it could improve the total system efficiency and reduce the efficiency penalty.

The performance of L-IGFC system has analyzed and calculated by using Microsoft Excel software. In this study, the total system performance is compared to the reference system with parameter constraints is maintained. The net power output of this study is $27,169.62 \mathrm{~kW}$ which is higher $608.421 \mathrm{~kW}$ than reference system eventhough the electric power consumption of this study is higher than reference system. More detail performance comparison results is shown in the following TABLE III.

TABLE III Performance COMPARISON With ReFERENCE CASE

\begin{tabular}{|c|c|c|}
\hline & $\begin{array}{l}\text { Reference } \\
\text { System [2] }\end{array}$ & This Study \\
\hline SOFC working temperature, ${ }^{\circ} \mathrm{C}$ & 850 & 850 \\
\hline SOFC working pressure, bar & 3.04 & 3.04 \\
\hline $\mathrm{T}_{\text {outlet }}$ of Dry Gas Desulfurization, ${ }^{\circ} \mathrm{C}$ & 460 & 460 \\
\hline $\mathrm{T}_{\text {inlet }}$ to SOFC module, ${ }^{\circ} \mathrm{C}$ & 509.7 & 509.7 \\
\hline $\mathrm{T}_{\text {inlet }}$ of steam to HRSG, ${ }^{\circ} \mathrm{C}$ & 339.4 & 339.4 \\
\hline Mass flow rate of steam to $\mathrm{HRSG}, \mathrm{kg} / \mathrm{h}$ & 68,000 & 68,000 \\
\hline \multicolumn{3}{|l|}{ Electric Power Output, kW } \\
\hline $\mathrm{SOFC}\left(@ \mathrm{i}=0.2 \mathrm{~A} / \mathrm{cm}^{2}\right)$ & $13,384.53$ & $12,625.86$ \\
\hline HPST1 & $4,060.75$ & $3,517.90$ \\
\hline LPST1 & $12,160.23$ & $10,852.03$ \\
\hline Raw Syngas Expander & 830.96 & $1,172.04$ \\
\hline Clean Syngas Expander & None & 57.82 \\
\hline Flue Gas Expander & $2,453.51$ & $2,507.55$ \\
\hline HPST2 & None & 352.69 \\
\hline LPST2 & None & $3,256.41$ \\
\hline Steam Turbine 1 & None & 393.29 \\
\hline Steam Turbine 2 & None & 850.56 \\
\hline Total & $32,889.98$ & $35,586.15$ \\
\hline \multicolumn{3}{|l|}{ Electric Power Consumption, kW } \\
\hline Air Compression & $3,575.08$ & $3,575.08$ \\
\hline Pump & 345.44 & 477.76 \\
\hline Nitrogen Compression & 111.63 & 111.63 \\
\hline Drying Blower & 7.83 & 7.83 \\
\hline $\mathrm{O}_{2}$ Separation and Compression & $2,288.8$ & $2,288.8$ \\
\hline Intercooling $\mathrm{CO}_{2}$ compressions & None & $1,955.43$ \\
\hline Total & $6,328.78$ & $8,416.53$ \\
\hline Net Power Output, kW & $26,561.19$ & $27,169.62$ \\
\hline Net LHV efficiency, \% & 60.32 & 62.50 \\
\hline $\mathrm{CO}_{2}$ removal ratio, $\%$ & - & 88.88 \\
\hline
\end{tabular}

The working SOFC temperature and pressure are maintained same with reference case, $850^{\circ} \mathrm{C}$ and 3 atm, respectively. Beside of that the outlet temperature of dry gas desulphurization, 


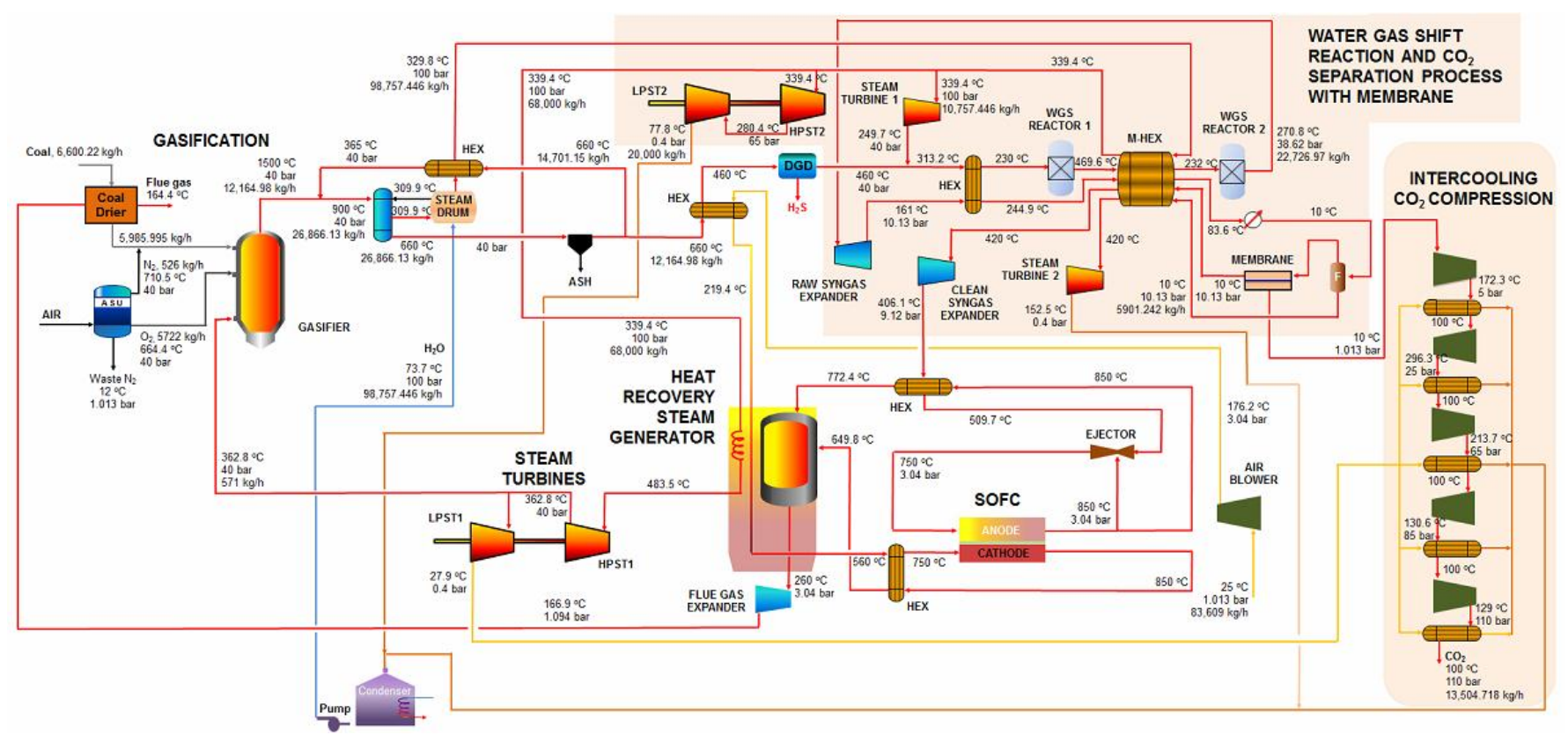

Fig. 1. Process Flow Diagram of the L-IGFC Plant with Membrane Based $\mathrm{CO}_{2}$ Capture Technology

inlet temperature to SOFC and to heat recovery steam generator as well as mass flow rate of steam are also maintained. In this study, the reference L-IGFC system, water gas shift reactors with $\mathrm{CO}_{2}$ membrane, and intercooling $\mathrm{CO}_{2}$ compression have been analyzed.

There is no significant changing occurred on the reference L-IGFC system unless the increase of mass flow rate of pumped water for steam drum and decreasing of inlet temperature of steam turbines (HPST1 and LPST1). The increase of water mass flow rate that pumped to the steam drum is occurred because of addition of the amount of water needed to generate steam for water gas shift reaction and electricity production through HPST2 and LPST2 in water gas shift reaction subsystem. It is followed by energy consumption of water pump. The inlet temperature decreasing of HPST1 and LPST1 is occurred because heat transfer to the steam is not enough.

Fortunately, this reduction can be covered by power generation in the water gas shift and $\mathrm{CO}_{2}$ membrane subsystem. Through utilization of waste heat and heat recovery system in multi-stream heat exchanger, the total electric power output reduction can be avoided. Four steam turbines are added to this proposed system in order to expand and generate energy from high temperature steam after waste heat recovery process. This proposed system can raise the total electric power output 2,696.17 kW compared to reference case.

The electric power consumption of this proposed system is higher than the reference case because it requires energy to pump the water that will deliver to the steam drum as well as need energy to compress $\mathrm{CO}_{2}$ to the storage with final $\mathrm{CO}_{2}$ pressure 110 bar. Although in such case, the net power output of the proposed system is still higher $608.421 \mathrm{~kW}$ compared to reference case. Thus, the total efficiency of the L-IGFC plant integrated with membrane-based $\mathrm{CO}_{2}$ capture technology is $62.50 \%$ which is 2.18 points higher than reference case and could remove $88.88 \% \mathrm{CO}_{2}$ compound in the L-IGFC plant.

\section{CONCLUSION}

The L-IGFC plant with membrane-based $\mathrm{CO}_{2}$ capture technology was proposed. The total efficiency of the plant including intercooled $\mathrm{CO}_{2}$ compressions is $62.50 \%$ in $\mathrm{LHV}$ which has 2.18 points higher than the reference system without $\mathrm{CO}_{2}$ capture technology. This proposed system could remove $88.88 \% \mathrm{CO}_{2}$ compound from the system. The integration of membrane-based $\mathrm{CO}_{2}$ capture technology and heat recovery system for steam generation in the L-IGFC plant could avoid the system from energy penalty.

\section{REFERENCES}

[1] B. N. Taufiq, Y. Kikuchi, T. Ishimoto, K. Honda, M. Koyama, Conceptual Design of Light Integrated Gasification Fuel Cell Based on Thermodynamic Process Simulation. Applied Energy 147 (2015) 486499. https://doi.org/10.1016/j.apenergy.2015.03.012

[2] B. N. Taufiq, Y. Kikuchi, T. Ishimoto, K. Honda, M. Koyama, Sensitivity Analysis for the Efficiency Improvement of a Light Integrated Gasification Fuel Cell Power Plant. ECS Transaction, 68 (1) 333-342 (2015).

https://doi.org/10.1149/06801.0333ecst

[3] S. Bachu. Review of $\mathrm{CO}_{2}$ storage efficiency in deep saline aquifers. International Journal of Greenhouse Gas Control 40 (2015) 188-202. https://doi.org/10.1016/j.ijggc.2015.01.007

[4] Z. Zhang, D. Huisingh. Carbon Dioxide Storage Schemes: Technology, Assessment and Deployment. Journal of Cleaner Production xxx (2016) $1-10$.

[5] D. Y. C. Leung. An Overview of Current Status of Carbon Dioxide Capture and Storage Technologies. Renewable and Sustainable Energy Reviews 39 (2014) 426-443. https://doi.org/10.1016/j.rser.2014.07.093

[6] E. S. Fernandez, M. Naylor, M. Lucquiaud, B. Wetenhall, H. Aghajani, J. Race, H. Chalmers. International Journal of Greenhouse Gas Control 52 (2016) 139-154. https://doi.org/10.1016/j.ijggc.2016.06.005

[7] R. Barker, Y. Hua, A. Neville. International Materials Reviews 2017 Vol.62 No.1. 
https://doi.org/10.1080/09506608.2016.1176306

[8] C. Descamps, C. Bouallou, M. Kanniche. Efficiency of an Integrated Gasification Combined Cycle (IGCC) Power Plant Including $\mathrm{CO}_{2}$ Removal. Energy 33 (2008) 874-881. https://doi.org/10.1016/j.energy.2007.07.013

[9] DOE/NETL. Cost and Performance Baseline for Fossil Energy Plants. Final Report 2007

[10] P. J. Robinson, W. L. Luyben. Integrated Gasification Combined Cycle Dynamic Model: $\mathrm{H}_{2} \mathrm{~S}$ Absorption/ Stripping, Water-Gas Shift Reactors, and $\mathrm{CO}_{2}$ Absorption/ Stripping. Industrial and Engineering Chemistry Research 49 (2010) 4766-4781. https://doi.org/10.1021/ie901549s

[11] T. Merkel. Membrane Process to Capture $\mathrm{CO}_{2}$ from Coal-Fired Power Plant Flue Gas. Final Report NETL/ DOE 2011.

[12] H. Lin. $\mathrm{CO}_{2}$-Selective Membrane for Hydrogen Production and $\mathrm{CO}_{2}$ Capture - Part II: Techno-Economic Analysis. Journal of Membrane Science 493 (2015) 794-806. https://doi.org/10.1016/j.memsci.2015.02.042

[13] R.W. Baker. Membrane Technology and Application, 2nd edition. John Wiley and Sons Ltd. England. 2004. https://doi.org/10.1002/0470020393

[14] R. Baker. Polymer Membranes in Processes to Produce Hydrogen with CO2 Capture. AiChE Annual Meeting Presentation, San Fransisco. November 2013. 